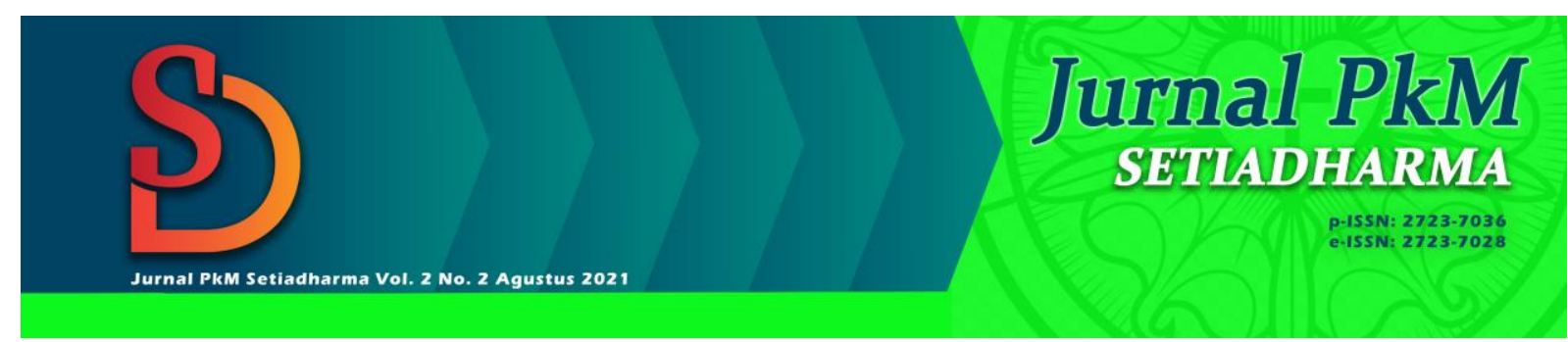

\title{
PENANAMAN NILAI KEWIRAUSAHAAN YANG ALKITABIAH KEPADA MASYARAKAT DUSUN BONENGGAYA DENGAN MEMBERDAYAKAN BAHAN BAKU JAHE
}

\author{
Lasmaria Rohani Pakpahan¹, Yulius Karipi Tanandima², Hempri Apriliyanto Salawaney33, \\ Raymon Imanuel Biaf ${ }^{4}$ \\ 1,3Sekolah Tinggi Teologi Injil Arastamar (SETIA) Jakarta \\ 2,4Sekolah Tinggi Teologi SAPPI Ciranjang \\ lasmariapakpahan58@gmail.com
}

Diterima:

08-07-2021

Direview:

28-07-2021

07-08-2021

Direvisi:

30-07-2021

09-08-2021

Diterbitkan:

30-08-2021

Keywords:

Bonenggaya,

Entrepreneurship,

Ginger, biblical

entrepreneurship,

poverty,

prosperity

Kata Kunci:

entreprenurship,

kewirausahaan

yang alkitabiah,

misi holistik,

kesejahteraan

\section{Abstract}

Bonenggaya hamlet is one of the places in Pakava Village, Riopakava District, Donggala Regency, Central Sulawesi Province which has great opportunities in improving the economy, but lack of knowledge so that local people do not know how to manage their natural products. increased so that it greatly affects poverty. The importance of the role of God's servants to provide insight for the community is not only to improve life in spirituality but to balance it with physical needs for the welfare of people's lives. Empowering the community in making instant ginger is one of the services carried out in the field to increase the level of the economy. Thus, this paper answers how to instill the values of entrepreneurship that are biblical or in accordance with God's word.

\section{ABSTRAK}

Dusun Bonenggaya merupakan salah satu tempat yang berada di desa pakava, Kecamatan Rio Pakava, Kabupaten Donggala, Provinsi Sulawesi Tengah. Kampung ini sekalipun miskin namun memiliki potensi untuk meningkatkan perekonomian. Karena disebabkan wilayah yang terasing dan terpencil membuat masyarakat setempat tidak mengetahui cara mengelola hasil alam yang dimiliki, masalah ini membuat tingkat perekonomian tidak meningkat sehingga sangat berpengaruh pada kemiskinan. Penelitian ini menggambarkan peran sentral hamba Tuhan untuk memberikan wawasan bagi masyarakat dalam hal entrepreneurship. Rohaniawan bukan hanya meningkatkan hidup dalam hal spiritual melainkan menyeimbangkan dengan kebutuhan jasmani demi kesejahteraan hidup masyarakat. Metode yang digunakan dalam penelitian berbasis masyarakat ini adalah metode partisipatif yang langsung mengajak masyarakat melakukan apa yang dicontohkan. Selain itu juga mengembangkan metode pendampingan. Memberdayakan masyarakat dalam pembuatan jahe instan merupakan salah satu pelayanan yang dilakukan di lapangan untuk menambah tingkat perekonomian. Dengan cara ini menunjukkan bagaimana masyarakat semakin maju dalam memahami produk lokal sebagai satu komoditi yang bisa menaikkan perekonomian. 


\section{PENDAHULUAN}

Salah satu contoh masalah sosial yang disebabkan oleh faktor ekonomi adalah kemiskinan. Dalam kekristenan sejak zaman Perjanjian Lama Allah telah memerintahkan orang beriman untuk menolong mereka yang kesusahan karena kemiskinan (Im. 25:23). Dalam kehidupan berbangsa, memberantas kemiskinan sesuai dengan Sila 5 Pancasila. Meskipun telah berjuang puluhan tahun untuk membebaskan diri dari kemiskinan, kenyataan memperlihatkan bahwa sampai saat ini Indonesia belum bisa melepaskan diri dari kemiskinan. ${ }^{1}$ Indra Maipita di awal bukunya menjelaskan bahwa kemiskinan merupakan fenomena atau suatu kenyataan yang belum dan takkan terhapuskan dari muka bumi ini. Hal ini disebabkan oleh perbedaan kemampuan, perbedaan kesempatan dan sumberdaya. ${ }^{2}$ Secara umum faktor-faktor yang menyebabkan kemiskinan antara lain: budaya, tingkat pendidikan yang masih rendah, letak geografis, beban hidup keluarga dan keterbatasan sumber daya alam. Faktor ini tampak jelas di masyarakat Bonenggaya. Faktor ini nampak jelas di masyarakat Bonenggaya. Badan Pusat Statistik (BPS) menyebutkan bahwa jumlah penduduk miskin sebanyak 27,55 juta orang di tahun 2020, situasinya meningkat sejak dari tahun 2019.3

Ngedi menyatakan, Alkitab mengatakan bahwa kemiskinan itu dimulai sejak manusia jatuh ke dalam dosa. Diketahui bahwa sebelum jatuh ke dalam dosa, manusia hidup dalam kelimpahan (bdk. Kej. 2), setelah jatuh ke dalam dosa manusia hidup dengan bersusah payah (bdk. Kej.3:17-19). ${ }^{4}$ Kekeliruan pemahaman tentang dosa berdampak pada pemahaman yang tidak tepat. Dosa tentu punya konsekuensi pada kerohanian dan jasmani. Tetapi kemiskinan tidak serta merta hanya karena dosa. Banyak faktor penyebab hal tersebut. Salah satunya kemalasan dan Pendidikan. Pada bagian ini dinyatakan bahwa untuk bertahan hidup manusia harus bekerja keras. Selanjutnya dalam Perjanjian Lama kemiskinan dideskripsikan dalam Keluaran 23:6,11, dan Imamat 24:17 serta kisah mengenai janda miskin di Sarfat (1Raj. 17:7-24), sedangkan dalam Perjanjian baru sendiri kemiskinan digambarkan sebagai keadaan yang berkekurangan (bdk. Luk. 4:18-19; 7:22). Maka perlu ada pelayanan holistik yang harus dipahami setiap hamba Tuhan sebagai panggilan dalam konteks Indonesia. Misi holistik begitu sentral bagi orang-orang Kristen. Pelayanan yang memperhatikan spiritual tetapi tidak mengabaikan makna kehidupan. Sebagaimana yang telah dirintis di Bonenggaya Bersama beberapa mitra. Pelayanan diakonia memperhatikan 3 aspek sebagai fokus, yaitu: Kerohanian, Pendidikan, Pengembangan Masyarakat. Pendekatan Holistik tepat dilakukan untuk pelayanan masyarakat terabaikan.

Hal yang sama juga saat ini dialami oleh masyarakat secara umum yang ada di Bonenggaya di desa Rio Pakava Kabupaten Donggala. Pada umumnya latar belakang pekerjaan masyarakat ialah petani. Mayoritas penduduk di Kecamatan ini masih digolongkan sebagai keluarga pra-sejahtera. Cenderung tertinggal dari berbagai aspek kehidupan manusia seperti pendidikan, ekonomi, seni, dan spiritual. 5 Seperti diketahui bahwa hasil utama masyarakat di Bonenggaya ialah tanaman kopi, kakao, dan beberapa

${ }^{1}$ Cahya Dicky Pratama, "Kemiskinan: Definisi, Jenisdan Faktor Peyebabnya," Kompas.Com, last modified 2021, accessed July 1, 2021,

https://www.kompas.com/skola/read/2020/11/24/172143169/kemiskinan-definisi-jenis-dan-faktorpenyebabnya?page=all.

2 Indra Maipita, Memahami Dan Mengukur Kemiskinan (Yogyakarta: Absolute Media, 2013), 1.

${ }_{3}^{3}$ BPS, https://www.bps.go.id/pressrelease/2021/02/15/1851/persentase-penduduk-miskin-september2020-naik-menjadi-10-19-persen.html diakses tanggal 30 Juli 2021.

4 Mika Daddu Ngedi, "PRAKTIK KEWIRAUSAHAAN GEREJA: Upaya Gereja Pentakosta Dalam Mengentaskan Kemiskinan Di Kota Wamena," Visio Dei: Jurnal Teologi Kristen 1, no. 1 (2019): 22.

5 Tony Salurante et al., "Melalui Pembangunan Gedung Sekolah Di Dusun Bonenggaya Kecamatan Rio Pakava Kabupaten Donggala Sulawesi Tengah" no.1 (2020): 11-13. 
jenis tanaman lainnya seperti jahe, cabai, dan serai. Jika dilihat secara sepintas, ini merupakan hasil alam yang cukup baik. Namun dalam pengelolaannya, terlihat bahwa masyarakat masih jauh dari yang bisa dibayangkan. Tingkat pengetahuan masih sangat rendah, sehingga hasil alam yang dimiliki tidak dapat dikelola dengan baik dan langsung dijual begitu saja dengan harga yang cukup murah. Sebagai contoh:

\begin{tabular}{|c|l|l|c|}
\hline No & Nama Barang & Satuan & Harga \\
\hline 1 & Kopi & $1 \mathrm{Kg}$ & Rp. 19.000 \\
\hline 2 & Kakao & $1 \mathrm{Kg}$ & Rp. 20.000 \\
\hline 3 & Cabai & $1 \mathrm{Kg}$ & Rp. 20.000 \\
\hline 4 & Jahe & $1 \mathrm{Kg}$ & Rp. 15.000 \\
\hline
\end{tabular}

Melihat dari tabel di atas, Jahe yang banyak ditanam di sekitar lingkungan punya nilai ekonomis lebih dibandingkan komoditi yang lain. Sekalipun penulis melihat bahwa masing-masing komoditi yang dijual masih tergolong rendah. Masyarakat juga belum punya keterampilan memproduksi hasil Padahal jika barang-barang tersebut diolah dengan baik, maka akan menghasilkan nilai jual yang tinggi. Berdasarkan pengetahuan dan pengalaman peneliti dalam pengelolaan pangan maka penulis ingin memberikan sesuatu yang baru bagi masyarakat dengan harapan dapat membantu mereka untuk meningkatkan potensi yang ada di Bonenggaya. Peneliti menyadari juga bahwa panggilan untuk melayani merupakan mandat yang diperintahkan oleh Tuhan Yesus kepada murid-murid-Nya, juga setiap orang percaya, dalam hal ini adalah hamba Tuhan.

Hamba Tuhan dipanggil untuk memberitakan kabar baik sebagai penyambung suara Allah untuk menyampaikan berita pengampunan Allah. Namun di dalam mengerjakan mandat tersebut, diakui bahwa situasi sulit dan sukar menuntut para pelayan untuk benar-benar berpikir secara holistik dalam menyikapi setiap masalah yang dialami oleh jemaat maupun masyarakat. Hamba Tuhan terpanggil untuk melayani secara rohani dan melayani juga secara jasmani sehingga hamba Tuhan tidak hanya tinggal diam untuk melihat masalah yang dihadapi oleh masyarakat, tetapi turut mengambil bagian demi tercapainya kesejahteraan jemaat/masyarakat. Oleh sebab itu, penting adanya suatu kajian tentang penanaman kewirausahaan yang alkitabiah terhadap masyarakat di Bonenggaya.

Adapun upaya yang dilakukan bertujuan untuk: (1) Sebagai strategi untuk membangun relasi dengan jemaat, (2) menambah wawasan/pengetahuan bagi jemaat agar kreatif dalam memanfaatkan hasil sumber daya alam yang dimiliki, (3) membangun hubungan sosial yang baik di antara kehidupan berjemaat, dan (4) untuk dapat dikonsumsi sehari-hari. Alasan untuk memilih jahe selain ketersediaan yang banyak di wilayah ini. Proses pembuatannya tidak terlalu sulit bagi penduduk yang mayoritas belum bisa berbahasa Indonesia ini. Jahe juga bisa digunakan oleh mereka sendiri untuk menghangatkan dan kesehatan.

Dengan demikian kehadiran hamba Tuhan juga terlibat dan berdampak baik bagi kehidupan sosial ekonomi masyarakat, seperti yang dikatakan oleh Bernadus Seran Kehik mengatakan bahwa:

Pemberdayaan masyarakat desa merupakan salah satu upaya untuk meningkatkan kesejahteraan masyarakat, melalui beberapa kegiatan antara lain peningkatan prakarsa dan swadaya masyarakat, perbaikan lingkungan dan perumahan, pengembangan usaha ekonomi desa, pengembangan lembaga keuangan desa serta 
kegiatan-kegiatan yang dapat meningkatkan kemampuan masyarakat dalam menaikkan hasil produksinya. ${ }^{6}$

Hal tersebut juga bertujuan meningkatkan pengelolaan potensi di lingkungan sekitar guna menghasilkan pendapatan masyarakat dan terbentuknya ketahanan ekonomi dan kemandirian. Strategi tersebut berguna untuk dilakukan oleh seorang pemimpin dengan harapan dapat berdampak pada pertumbuhan gereja juga kesejahteraan masyarakat. Junior N. Silalahi juga mengatakan bahwa para pendeta maupun penginjil saat ini dapat menggunakan keahlian yang dimiliki untuk mendukung kegiatan dalam pelayanan. ${ }^{7}$ Tentunya hal ini sejalan dengan apa yang dikatakan oleh Simon Julianto bahwa: Kewirausahaan (entrepreneurship) merupakan proses berpikir dari seseorang dengan tujuan akan menciptakan usaha baru atau upgrading usaha yang lama akan semakin menjadi inovatif dan bernuansa selalu baru. ${ }^{8}$ Ada banyak hal yang bisa dilakukan di sini untuk meningkatkan perekonomian masyarakat, saat ini dipilih jahe yang memiliki manfaat juga untuk Kesehatan keluarga dan ekonomi.

\section{METODE PELAKSANAAN}

Metode pelaksanaan kegiatan Pengabdian kepada Masyarakat ini dilakukan dalam 5 kali pertemuan sejak bulan April-Juni 2021. Karena penduduk tidak banyak aktivitas maka waktu yang dipilih lebih fleksibel. Kaum ibu di sini terdiri dari 53 orang, kelompok menjadi 5 kelompok. Nantinya mereka akan melakukan tugas bersama-sama dan masing-masing memberikan penilaian. Metode yang diterapkan dalam kegiatan ini adalah partipatif. Semua orang yang ikut mencoba mempraktikkan berbagai proses yang diajarkan. Di samping itu metode pendampingan sangat diperlukan. Mengoreksi dan memberi arahan yang langsung dipraktikkan. Mereka terlibat aktif dan langsung mencoba setiap tahap demi tahap. Dijadwalkan pukul 09.00-14.00 WITA berlokasi di pendopo masyarakat yang biasa disebut Bantayan. Penelitian ini juga akan membahas secara deskriptif terkait dengan pandangan teologis kepada wirausaha jemaat. Sehingga terjadi kombinasi dalam artikel ini. Data yang diambil berasal dari beberapa sumber yang bisa memperkuat dasar dari kegiatan Pengabdian kepada Masyarakat ini.

\section{HASIL DAN PEMBAHASAN} berikut:

Metode pengabdian masyarakat yang digunakan dibagi dalam tiga sesi sebagai

\subsection{Kegiatan sesi 1}

Kegiatan sesi pertama dilakukan oleh fasilitator. Fasilitator melakukan penjelasan dan praktik yang langsung dilihat dan diperagakan oleh ibu-ibu setempat. Karena mayoritas kaum ibu masih buta huruf maka cara penjelasan dan praktik yang diterjemahkan oleh sdr. Bama. Dalam hal ini fasilitator juga dibantu oleh 2 rekan hamba Tuhan dari STT SAPPI Cirajang Bernama saudara Yulius Karipi dan Romi. Ibu-ibu sudah

\footnotetext{
${ }^{6}$ Bernardus Seran Kehik, "Pelaksanaan Program Pemberdayaan Masyarakat Desa Di Bidang Ekonomi Kemasyarakatan (Studi Kasus Di Desa Naiola Kecamatan Bikomi Selatan Kabupaten Timor Tengah Utara)," Jurnal Agribisnis Lahan Kering, Agrimor 3, no. 1 (2018): 5.

${ }^{7}$ Junior Natan Silalahi, "PAULUS SANG ENTREPRENEUR: Pembuat Tenda Sebagai Jembatan Penginjilan,” Visio Dei: Jurnal Teologi Kristen 1, no. 1 (2019): 16.

8 Simon Julianto, "Kewirausahaan Jemaat: Sebuah Alternatif Berteologi," WASKITA, Jurnal Studi Agama dan Masyarkat 3, no. 1 (2016): 155.
} 
membawa masing-masing jahe yang mereka miliki yang akan dikumpulkan bersama. Diajarkan bagaimana membersihkan jahe dan mempersiapkan untuk proses pembuatan bubuk jahe.

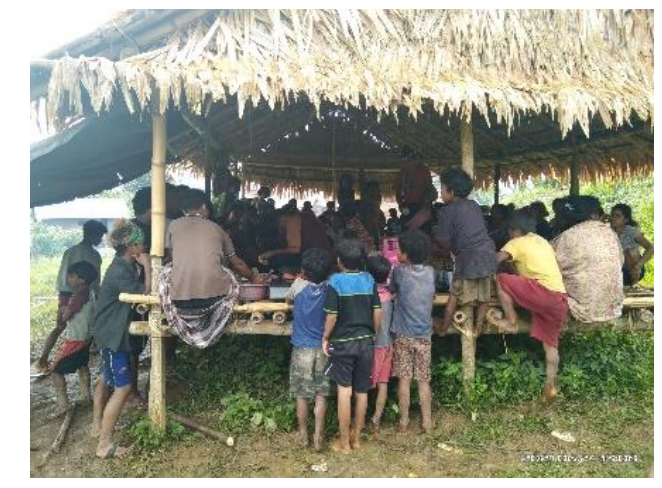

Gambar 1.1 Warga antusias mendengarkan Penjelasan dari nara sumber

\subsection{Kegiatan sesi 2}

Pelaksanaan pada sesi kedua yaitu Penyuluhan serta penjelasan mengenai tanaman jahe dan manfaatnya bagi kesehatan tubuh serta dapat diolah sebagai hasil tanaman sendiri sehingga menghasilkan nilai jual yang cukup tinggi untuk membangun perekonomian jemaat. Pada sesi ini saya dibantu oleh rekan hamba Tuhan lain yaitu Hempri Apriliyanto Salawaney. Penyuluhan pada saat ini juga sekaligus untuk mendorong ibu-ibu untuk menanam sebanyak mungkin Jahe di sekitar kebun dan pemukiman.

\subsection{Kegiatan sesi 3}

Pelaksanaan pada sesi ketiga yaitu Pelatihan memasak pembuatan jahe instan dengan melibatkan kaum ibu secara langsung. Menyediakan bahan-bahan dan alat-alat utama dalam pembuatan jahe instan seperti jahe, gula, serai, daun pandan, tungku/kayu bakar serta wajan untuk memasak. Di bagian ini, fasilitator juga menunjukkan bagaimana pengemasan yang standar sesuai dengan kondisi di bonenggaya

Sebelumnya, selama 1 bulan dilakukan secara berulang-ulang dari kelompok yang sudah terbagi. Mereka akan saling belajar dan memberi koreksi. Dengan demikian akan muncul kepercayaan diri di antara ibu-ibu. Meskipun sebagian ibu-ibu masih sulit untuk berbahasa Indonesia, komunikasi di saat sosialisasi dapat berjalan dengan baik. Ibu-ibu begitu antusias dan setia mengikuti kegiatan setiap kali ada pertemuan.

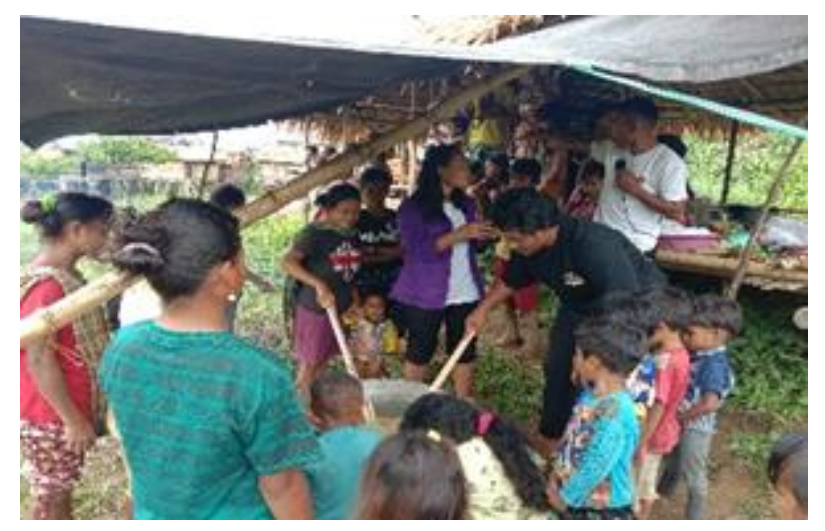

Gambar 1.2 Ibu-ibu mempraktikkan teori yang sudah diajarkan 
Asal kata kewirausahaan atau Entrepreneur berasal dari bahasa Prancis di mana pengertiannya bisa diartikan kontraktor. Yang asal katanya ialah Entreprenant yang berarti giat, mau berusaha, berani, penuh petualangan dan entreprendre yang berarti undertake. Dalam sejarahnya kemudian istilah Entrepreuner dipergunakan dalam bahasa Inggris sejak tahun 1878 dan dipahami sebagai a contractor acting as intermediary between capital and labour. ${ }^{9}$

Sedangkan konsep wirausaha secara historis digagas oleh Richard Castillon pada tahun 1755, sedangkan di Indonesia baru dikenal pada akhir abad 20. Di Belanda istilah ini dikenal dengan ondernemer, di Jerman dikenal dengan Unternehmer. ${ }^{10}$ Karena kewirausahaan ini penting dalam masyarakat sosial maka pendidikan Kewirausahaan sendiri sudah dirintis pada tahun 1950-an di beberapa negara seperti Eropa, Amerika, dan Kanada. Tidak hanya sampai disitu sejak tahun 1970-an, banyak universitas yang mengajarkan kewirausahaan atau manajemen usaha kecil. Demikian juga yang terjadi di Indonesia di kemudian hari.

Namun demikian di Indonesia, kewirausahaan dipelajari baru terbatas pada beberapa sekolah atau perguruan tinggi, belum dijadikan sebuah perhatian yang serius oleh pemerintah. ${ }^{11}$ Mengacu pada latar belakang masalah di atas, maka salah satu faktor yang menyebabkan kemiskinan di Indonesia adalah pengetahuan atau pendidikan. Jika pendidikan dan pengetahuan sudah tersebar luas dan merata di seluruh bagian Indonesia, mungkin situasinya bisa berbeda. Sehingga bisa mendorong peningkatan kesejahteraan masyarakat. Hal ini sejalan dengan apa yang dikatakan oleh Nisfua Riska D. dalam artikel perkembangan kewirausahaan di Negara Indonesia bahwa Kewirausahaan sendiri dikatakan sebagai salah satu faktor yang dapat mendorong peningkatan perekonomian di Indonesia dengan alasan:

(1) mampu meningkatkan kreativitas dan kemampuan setiap warga dalam menyalurkan ide dan kreasinya;

(2) masyarakat menjadi mandiri tidak tergantung pada pemerintah belaka;

(3) dapat menarik investor Negara asing untuk menanamkan modalnya di Indonesia apabila kewirausahaan berjalan dengan baik. ${ }^{12}$

Lebih lanjut, bagi Schumpeter wirausaha adalah seseorang yang bisa mendobrak sistem ekonomi yang ada dengan memperkenalkan barang dan jasa yang baru, dengan menciptakan bentuk organisasi baru atau mengolah bahan baku baru. ${ }^{13}$ Wirausaha bukan sesuatu yang baru dalam kehidupan masyarakat sosial.

Dalam Alkitab telah mengisahkan beberapa orang yang berusaha untuk mencukupkan kebutuhan hidup dan pelayanannya. Beberapa tokoh Alkitab yang bisa dijadikan panutan dalam bidang kewirausahaan di antaranya adalah Abraham (Kej. 13, 14, 19, 21), Salomo (1Raj. 5, 9), dan Lydia dari Tiatira (Kis. 16:14-15, 40). Bingkai dari pemahaman tentang wirausaha tidak sebatas dalam hal perekonomian saja, namun juga masuk dalam kajian sosiologi dan teologi, termasuk di dalamnya psikologi. ${ }^{14}$ Dalam penelitian ini pemahaman teologi menjadi dasar peneliti untuk mendorong masyarakat

\footnotetext{
${ }^{9}$ Heri Cahyo Bagus Setiawan and Nuzulul Fatimah, Dasar-Dasar Kewirausahaan (Sidoarjo: Berkat Mukmin Mandiri, 2020), 4-6.

${ }^{10}$ Diah Lydianingtrias, dkk, Kewirausahaan Teknik Sipil (Malang: Polinema Press, 2018), 9.

11Ibid.

12 Nisfuah Rizka D, “Perkembangan Kewirausahaan Di Negara Indonesia,” Blog, last modified 2016, accessed June 28, 2021, http://blog.ub.ac.id/nisfuahrizka/2016/09/12/perkembangan-kewirausahaandi-negara-indonesia/,.

${ }^{13}$ Ibid. 1.

${ }^{14}$ Suwarto Adi, "Kewirausahaan Dan Panggilan Kristen : Sebuah Pendekatan Interpretatif-," KURIOS (Jurnal Teologi dan Pendidikan Agama ... 6, no. 1 (2020): 20, http://sttpb.ac.id/ejournal/index.php/kurios/article/view/123.
} 
mampu berkembang keluar dari kemiskinan mereka. Tindakan ini butuh keberanian dan usaha.

Lebih lanjut jika wira diartikan sebagai berani dan usaha diartikan sebagai kegiatan bisnis, maka kewirausahaan dapat diartikan sebagai hal-hal yang bersangkutan dengan keberanian seseorang untuk melaksanakan sesuatu kegiatan secara mandiri baik bisnis maupun nonbisnis. Max Scraackhouse mengatakan bahwa berbicara mengenai kewirausahaan atau wirausaha tidak terlepas dari karakter ekonomi suatu Masyarakat yang mana karakter ekonomi tersebut mempunyai andil besar dalam terbentuknya budaya wirausaha. ${ }^{15}$ Dengan demikian maka penulis menyimpulkan bahwa kewirausahaan adalah upaya untuk membuat terobosan baru dengan cara menciptakan peluang usaha sesuai dengan potensi yang ada di tempat tertentu dengan tujuan agar dapat menambah wawasan pengetahuan serta menciptakan lapangan pekerjaan.

\section{Pandangan Alkitab terhadap Kewirausahaan}

Pemberdayaan ekonomi dalam masyarakat atau jemaat menjadi hal yang digumuli sampai saat ini, di mana ada berbagai pendapat mengenai hal ini. Ada yang berpendapat bahwa pemberdayaan ekonomi menjadi bagian yang tidak penting. Yang bisa terjadi dengan alami sesuai dengan kondisi. Sedangkan ada yang berpendapat bahwa ini menjadi bagian yang sangat penting. Penulis sendiri memahami bahwa ini menjadi bagian yang sangat penting mengacu pada pelayanan Tuhan Yesus ketika Ia melayani Ia selalu memberi makan semua orang, sehingga ini menjadi bagian dari refleksi penulis dengan cara melakukan teologi kewirausahaan. Utamanya pelayanan di sebuah wilayah yang masih hidup dalam sejahtera. Hal ini sejalan dengan apa yang dikatakan oleh Paul Stevens bahwa misi penatalayanan Allah mencakup penatalayanan kreasional, keadilan, ekonomi, pengembangan masyarakat, pemulihan hubungan dengan Allah, dan kepedulian terhadap sesama. ${ }^{16}$ Ini adalah pelayanan holistik, di mana seorang rohaniawan melihat juga hal-hal lain yang perlu diberikan kepada jemaatnya selain berbicara tentang kerohanian.

Dalam Lukas 10:25-37, ketika seorang ahli Taurat sengaja menjebak Yesus dengan suatu pertanyaan "Siapakah sesamaku manusia?", lalu Yesus menjawab bahwa sesama manusia adalah ia yang jatuh ke tangan seorang penyamun. Melalui kisah ini jelas bahwa yang dimaksud dengan sesama adalah sang korban. John Simon menjelaskan bahwa yang menjadi korban adalah kaum miskin, tertindas, baik secara fisik, rohani dan orang yang terpinggirkan secara strata sosial. ${ }^{17}$ Dilanjutkan lagi bahwa Allah memihak orang miskin karena mereka berada dalam penderitaan, sakit penyakit dan mengharapkan kebebasan dari belenggunya. Belenggu itu membuat seseorang menjadi sakit dan terbelakang. Kehadiran seorang hamba adalah untuk membebaskan mereka yang terbelenggu karena kuasa si jahat. Kehadirannya dalam sebuah komunitas membawa sebuah transformasi baik dari segi spiritual maupun jasmani. Kekuatan ini terjadi karena ada kuasa Roh Kudus yang menggerakkanya. ${ }^{18}$ Roh kudus menyadari akan keberdosaan manusia melalui proses setiap orang yang telah diterangi hidupnya

15 Preston Williams, On Moral Busines: Classical and Contemporrary Resources for Ethic in Economy Life, ed. Max L. Stackhouse, Dennis P. McCann, and Shirley J. Roels (Grand Rapids: Eerdmans, 1995), 91.

16 Paul Stevens, God's Business: Memaknai Bisnis Secara Kristiani (Jakarta: BPK Gunung Mulia, 2006), 109.

${ }^{17}$ John Simon and Stella Y. E. P, Pembangunan Ekonomi Gereja (Yogyakarta: Kanisius, 2020), 76.

18 Tony Salurante, Dyulius Th Bilo, and David Kristanto, "Transformasi Komunitas Misi: Gereja Sebagai Ciptaan Baru Dalam Roh Kudus,” KURIOS (Jurnal Teologi dan Pendidikan Agama Kristen) 7, no. 1 (2021): 130-134. 
mempengaruhi orang di sekitarnya. Transformasi dalam komunitas bagian yang menjadi strategi dalam pelayanan rasul juga, tidak hanya fokus kepada jiwa personal saja. Dalam hal ini orang percaya bertumbuh dalam komunal dan saling memperhatikan.

Dengan demikian Penulis menyadari bahwa pemahaman akan teologi kewirausahaan yang baik merupakan salah satu panggilan misi yang juga punya peran penting. Ini dilakukan untuk memberdayakan ekonomi masyarakat yang terbelenggu kemiskinan. Langkah ini harus dilakukan untuk memulai sesuatu. Hal ini mengacu kepada pemahaman bahwa dunia ini adalah milik Allah yang harus kita pertanggungjawabkan secara kreatif Allah bekerja dengan baik, Ia membentuk, membuat, menghasilkan, menghancurkan, memperbaiki, memulihkan, dan merancang kembali. Itulah pekerjaan yang Ia lakukan. oleh karena itu, melalui pekerjaannya ini memotivasi kita yang datang sebagai tamu di bumi untuk melakukan pekerjaannya juga.

Pengolahan jahe berupa minuman bubuk instan yang berbentuk serbuk, yang terbuat dari jahe yang ditambah gula dan rempah-rempah lainnya. Minuman instan yang diolah dalam bentuk serbuk serta praktis dalam penyajian dan memiliki daya simpan yang cukup lama karena kadar airnya yang rendah dibandingkan dengan minuman dalam bentuk cairan.

Minuman jahe sendiri memiliki sifat dan kandungan yang berkhasiat dalam meredakan dan menumpas berbagai penyakit baik ringan maupun berat seperti:

- gangguan pencernaan seperti radang lambung dan saluran empedu

- gangguan pernapasan seperti asma,

- tersumbatnya pembuluh darah, mual dan rasa ingin muntah

- $\quad$ sakit perut, kembung dan mulas

- $\quad$ kejang-kejang

- $\quad$ sulit buang angin

- nafsu makan berkurang

- ASI tidak lancar

- Gatal-gatal

- Kanker Ovarium

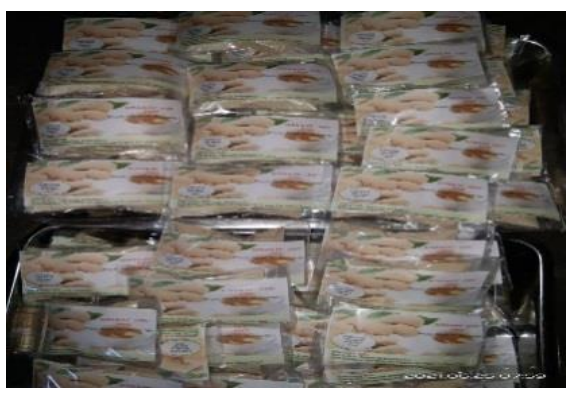

Gambar 1.3 Contoh Produk yang sudah jadi

- $\quad$ Rematik, nyeri persendian

- $\quad$ Pusing/sakit kepala. ${ }^{19}$

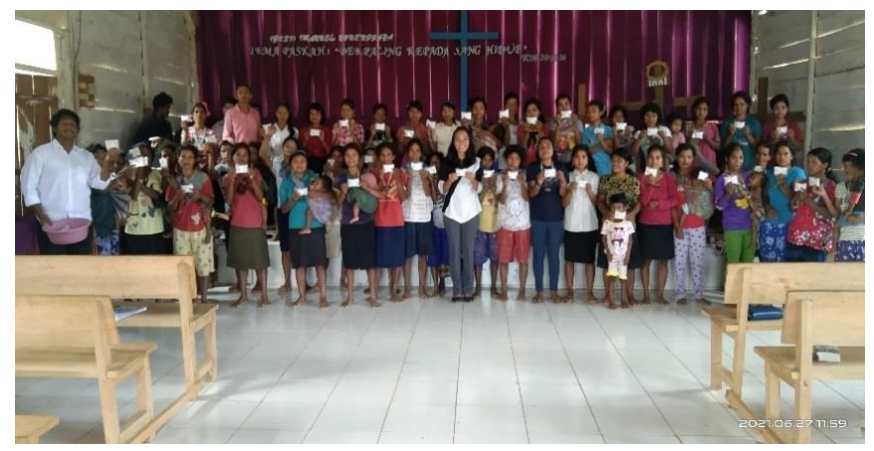

Gambar 1.4 seluruh ibu-ibu menunjukkan hasil karya

\section{KESIMPULAN}

Kegiatan dalam meningkatkan perekonomian masyarakat Bonenggaya memerlukan bimbingan holistik dan kesabaran. Dasarnya adalah kasih untuk melihat sesama hidup 
lebih sejahtera. Hasil dari Pengabdian pada Masyarakat telah memicu kesadaran ekonomi baru bagi penduduk. Memberdayakan masyarakat dalam pembuatan minuman jahe instan merupakan solusi yang bermanfaat kepada ekonomi dan alternatif minuman untuk kesehatan tubuh. Semakin banyak warga mulai menanam jahe dan mencobanya sendiri. Banyaknya penyakit yang timbul karena cara mengkonsumsi makanan yang tidak terjaga dan keberadaan cuaca di tempat praktik melayani curah hujan yang sangat tinggi menyebabkan masyarakat cenderung bersikap hati-hati. Harapan kami supaya pengetahuan tersebut dapat terus meningkat. Pelayanan ini untuk bersama-sama mengajak para Hamba Tuhan lain sebagai pelayanan Tuhan untuk tidak hanya melakukan pelayanan yang sifatnya rohani saja tetapi juga sifatnya yang jasmani yaitu holistik.

\section{SARAN}

Perlu adanya program berkelanjutan untuk mengembangkan segala potensi yang ada di Dusun Bonenggaya dan masyarakat lebih kreatif dalam mengembangkan hasil alam untuk meningkatkan perekonomian masyarakat.

\section{UCAPAN TERIMA KASIH}

Pada kesempatan ini penulis mengucapkan terima kasih kepada Mitra Misi yang terdiri dari GKI Kota Wisata Cibubur, GKI Kav. Polri, GKI Palu, GKIm Hosana Bandung. Ketua Sektor Gereja Kristen Setia Indonesia di Mamuju. Dan juga dosen Pembimbing dari STT Setia Jakarta. Demikian halnya kepada bapak kepala Dusun Bonenggaya dan kaum ibu GKSI Bonenggaya beserta rekan Hamba Tuhan yang ada yang telah ikut mendukung dan berpartisipasi berlangsungnya program pengabdian kepada Masyarakat ini.

\section{DAFTAR PUSTAKA}

Adi, Suwarto. "Kewirausahaan Dan Panggilan Kristen : Sebuah Pendekatan Interpretatif." KURIOS (Jurnal Teologi dan Pendidikan Agama ... 6, no. 1 (2020): 18-34. http://sttpb.ac.id/e-journal/index.php/kurios/article/view/123.

D, Nisfuah Rizka. "Perkembangan Kewirausahaan Di Negara Indonesia." Blog. Last modified 2016. Accessed June 28, 2021. http://blog.ub.ac.id/nisfuahrizka/2016/09/12/perkembangan-kewirausahaan-dinegara-indonesia/,.

Julianto, Simon. "Kewirausahaan Jemaat: Sebuah Alternatif Berteologi." WASKITA, Jurnal Studi Agama dan Masyarkat 3, no. 1 (2016): 151-181.

Kehik, Bernardus Seran. "Pelaksanaan Program Pemberdayaan Masyarakat Desa Di Bidang Ekonomi Kemasyarakatan (Studi Kasus Di Desa Naiola Kecamatan Bikomi Selatan Kabupaten Timor Tengah Utara)." Jurnal Agribisnis Lahan Kering, Agrimor 3, no. 1 (2018): 4-6.

Maipita, Indra. Memahami Dan Mengukur Kemiskinan. Yogyakarta: Absolute Media, 2013.

Ngedi, Mika Daddu. "PRAKTIK KEWIRAUSAHAAN GEREJA: Upaya Gereja Pentakosta Dalam Mengentaskan Kemiskinan Di Kota Wamena." Visio Dei: Jurnal Teologi Kristen 1, no. 1 (2019): 19-37.

Pratama, Cahya Dicky. “Kemiskinan: Definisi, Jenisdan Faktor Peyebabnya.” 
Kompas.Com. Last modified 2021. Accessed July 1, 2021. https://www.kompas.com/skola/read/2020/11/24/172143169/kemiskinandefinisi-jenis-dan-faktor-penyebabnya?page=all.

Salurante, Tony, Dyulius Th Bilo, and David Kristanto. "Transformasi Komunitas Misi: Gereja Sebagai Ciptaan Baru Dalam Roh Kudus." KURIOS (Jurnal Teologi dan Pendidikan Agama Kristen) 7, no. 1 (2021): 136-148.

Salurante, Tony, Malik Riswan, Karlina Wau, Sekolah Tinggi, Teologi Injili, and Arastamar Setia. "MELALUI PEMBANGUNAN GEDUNG SEKOLAH DI DUSUN BONENGGAYA KECAMATAN RIO PAKAVA KABUPATEN DONGGALA SULAWESI TENGAH" (n.d.): 10-18.

Sartika, Resa. Mudah Dan Praktis Dari Budidaya Jahe. Yogyakarta: Shira Media, 2017. Setiawan, Heri Cahyo Bagus, and Nuzulul Fatimah. Dasar-Dasar Kewirausahaan. Sidoarjo: Berkat Mukmin Mandiri, 2020.

Silalahi, Junior Natan. "PAULUS SANG ENTREPRENEUR: Pembuat Tenda Sebagai Jembatan Penginjilan.” Visio Dei: Jurnal Teologi Kristen 1, no. 1 (2019): 1-18. Simon, John, and Stella Y. E. P. Pembangunan Ekonomi Gereja. Yogyakarta: Kanisius, 2020.

Stevens, Paul. God's Business: Memaknai Bisnis Secara Kristiani. Jakarta: BPK Gunung Mulia, 2006.

Williams, Preston. On Moral Busines: Classical and Contemporrary Resources for Ethic in Economy Life. Edited by Max L. Stackhouse, Dennis P. McCann, and Shirley J. Roels. Grand Rapids: Eerdmans, n.d. 